\title{
Making America Great Again?
}

\author{
Jeffrey C. Isaac
}

$T$ his is my final editorial Introduction as editor of Perspectives on Politics.

Over the past twelve years as Book Review Editor, I have commissioned, carefully read, and line-edited approximately 4,000 reviews of political science books. Over the past eight years as Editor in Chief, I have reviewed almost 2,000 article submissions and have carefully read and line-edited the almost 200 articles we have published. I have corresponded with thousands more than the 6,000 authors whose work I have reviewed. This of course confers no special privilege on what I think about political science! But it cannot be denied that what I think is based on a rather sustained, extensive, and intensive experience of engaging the political science discipline and a great many of its practitioners.

Readers of this journal will know that I have not been hesitant to say what I think. Many readers have appreciated this. Some, not so much. And that is fine. Most academic journals, and especially scientific journals centering on peer review, are edited on the basis of a conceitthat editors are basically curators of anonymous processes whereby individual scholars submit their work for evaluation and publication. Anyone who has ever edited a significant journal or who has participated in a serious editorial process of revision and resubmission knows that this conceit is a fiction. Intellectual judgments are essential at every phase of the editorial process. Because the mission and indeed the very title of Perspectives on Politics embraces the perspectival character of political science inquiry, and also because I am the person that I am, I have embraced my own role as a facilitator of broad disciplinary discussion of important political problems. We have sought to publish work that bridges conventional subfield and methodological divides, to feature a genuine synergy of formatsarticles, essays, review essays, critical dialogues, book symposia, standard book reviews — and to highlight broad themes. And I have used my own Editor Introductions to discuss the contents of each issue in a way that expands on these themes.

I have decided to do things a bit differently here. I will first offer some comments about the contents of this issue and, true to form, I will do so provocatively, under the heading of the question posed at the top. But I will then adopt a more personal tone, and offer some general remarks of gratitude to those with whom I have worked, especially James Moskowitz, and best wishes to those who will carry this journal forward, my friends and colleagues Michael Bernhard and Dan O'Neill.

The contents of this issue of Perspectives are diverse, and surely lack an overall thematic focus. Why, then, try to discuss them under the heading of "Making America Great Again?" The answer is simple: because this slogan, which helped propel Donald Trump into the White House, is "in the air," so to speak, and many of the pieces contained here help us to reflect critically upon it. Trump's rhetoric invites us to imagine a time when America was strong, true, unified and perhaps even homogenous. It is a particular version of "American exceptionalism," linked to a dark vision of the world ("this American carnage stops right here") and unlinked from all of those things that have animated the more conventional, liberal version of exceptionalism widely lionized by cultural commentators at least since Daniel Boorstin published The Genius of American Politics in 1953 and Louis Hartz published The Liberal Tradition in America in 1955, and especially disconnected from the idea of constitutional democracy. It is obvious that "Trumpism" is a distinctively American version of the rise of right-wing, nationalist populism, and "illiberal democracy," that is unfolding in many parts of the world, especially in Europe. In recent months, a great many political science colleagues who write about right-wing populism or authoritarianism in places as far ranging as Russia, China, Turkey, and Egypt have published piecesin The Monkey Cage, Foreign Affairs, Vox, and a variety of other outlets-about the lessons that American scholars and citizens can learn from these places about current events in the United States. These writers are by and large "comparativists," which is to say they are participants in a subfield of U.S. political science centered on the idea that it is important to compare the political systems and political developments of different countries, and to identify common patterns, institutions, and processes as well as differences. And they have been speaking in part to colleagues in another subfield of the discipline, so-called "Americanists," who presumably are not very interested in 
comparison, but are very devoted to analyzing the institutions, and institutional lacunae, of the United States.

The idea that there is "American politics" over here, and "comparative politics" and "international relations" or "political theory" over there, is a rather quaint version of the very American exceptionalism of which Boorstin and Hartz wrote-though it is worth noting that both of those writers were historians with strong comparative sensibilities. It invites us essentially to take for granted that the United States is a constitutional democracy, even if a flawed one, and to focus our attention on various features of its distinctive system-the Constitution, Congress, interest groups and parties, etc.-with little regard for the way things are, and have come to be, anywhere else, and with little sense that some of the disturbing things we have no trouble identifying elsewhere-corruption, violence, bitter political conflict, radical ideologies, dictatorial tendencies - are relevant to what has been and is going on here. Now. The phenomenon of Trumpism raises serious questions about these assumptions, and has brought to the fore a theme that I have frequently articulated in Editor statements of this journal: that the subfield divisions are arbitrary, and that the United States really needs to be considered a polity among many, and not some exceptional "city on a hill" (see especially the December 2011 issue, which featured an essay by Alfred Stepan and Juan Linz on "Comparative Perspectives on Inequality and the Quality of Democracy in the United States").

The principal articles and essays published in this issue of Perspectives are not primarily concerned with the questions raised above. At the same time, each advances an "unexceptionalist" approach to American politics and even to what we mean when we speak of "America," a term that designates two continents, and perhaps the entire "Western hemisphere," as much as it does the particular nation-state officially named not "America" but "the United States of America.”

Adam Dahl's “The Black American Jacobins: Revolution, Radical Abolition, and the Transnational Turn" draws upon recent work in cultural studies on "Transatlanticism" to complicate conventional understandings of the role of race in U.S. political history. To give a flavor of his argument, I can do no better than to quote directly from Dahl's abstract:

While scholars of African American political thought have done a remarkable job centering focus on black thinkers, they still largely frame their endeavor in reference to the geo-political boundaries of the U.S. nation-state, thereby ignoring the transnational and diasporic dynamics of black politics. The consequence is that alternative traditions of thought in the Americas-e.g., Caribbean traditions-are cast as irrelevant to questions of racial exclusion in U.S. political thinking. This article seeks to correct nation-centric perspectives on U.S. political thought and development by demonstrating the utility of the 'transnational turn.' Drawing on the framework developed in CLR James' The Black Jacobins, it traces how an influential cohort of abolitionists in the antebellum United States looked to the Haitian Revolution as a model for the overthrow of slavery. Engaging the writings and speeches of David Walker, James Theodore Holly, and Frederick Douglass, it then argues that radical abolitionists operated in the same ideological problemspace as Haitian revolutionaries and adopted a specific model of revolution as much indebted to Haitian political thought as Anglo-American models of anti-colonial revolt. By implication, racially egalitarian movements and moments in U.S. political development cannot be adequately understood with exclusive reference to national traditions of thought.

Dahl's article is a contribution to the discourse often called "the history of American political thought"a scholarly domain nicely featured in the journal American Political Thought, brought out by University of Chicago Press in 2011. At the same time, Dahl's piece calls this domain into question, in the same way that it implicitly calls into question the very idea of American exceptionalism: "It is only by accepting the assumption that problemspaces seamlessly map onto geo-political borders that the United States can serve as the stable referent for the body of theoretical knowledge we call 'American political thought."'

Alison McQueen and Burke Hendrix similarly problematize conventional tropes about American national identity in their "Tocqueville in Jacksonian Context: American Expansionism and Discourses of American Indian Nomadism in Democracy in America." Readers of U.S. newspapers will know that Andrew Jackson is a hero of Donald Trump, who in April 2017 declared that "I mean, had Andrew Jackson been a little later, you wouldn't have had the Civil War. He was a very tough person, but he had a big heart." Jackson was in fact very tough, but not so warm-hearted; he was one of the most forceful advocates of "Indian removal" in early nineteenthcentury U.S. history, and the Indian Removal Act that he signed as President in 1830 laid the basis for the removal of all American Indians living east of the Mississippi River. For McQueen and Hendrix, these removals helped to define American political development and they represent an important context for understanding the writings of Alexis de Tocqueville:

Tocqueville's discussion of American Indians in Democracy in America is often read as the paradigmatic expression of a conventional story about American political expansion. This narrative holds that westward expansion was easy, in part because American Indians did not offer much resistance. Historians of political thought and scholars of American Political Development tend to affirm this narrative when they read Tocqueville's text as suggesting merely that Indians are 'doomed' to an inevitable extinction. Our interpretation in this article proceeds along different lines, with a greater focus on the ways in which contending Jacksonian-era discourses of Indian nomadism are represented in Tocqueville's text. We argue that Democracy reflects complex and often competing descriptions of inherent Indian nomadism, retreat, and removal, with varying attributions of causal responsibility for disappearing Indian populations. This 
reading of Tocqueville highlights features of contentions about Indian removal that are often ignored or neglected in current scholarship, and can therefore help us to better appreciate both his text and his time.

Sandipto Dasgupta's "Gandhi's Failure: State and Social Change during Postcolonial Transition" is not about anything distinctively "American" at all. While Gandhi has come to be regarded as an icon of resistance to colonialism and to injustice more generally, Dasgupta focuses on the fact that "Gandhi's vision of a polity constituted around decentralized village republics and constructive programme was comprehensively rejected." Dasgupta delineates and explains the "paradoxical marginalization" of Gandhi by placing him in dialogue with two contemporaries who each, in their own ways, played a more important role in shaping the future of postindependence India: B.R. Ambedkar, the jurist and activist who strongly criticized a pastoral vision of Indian society centered on the caste system, and Jawaharlal Nehru, India's first Prime Minister and the most important figure in the construction of India's post-colonial state. As Dasgupta writes: "these two lines of critiques-Gandhi as a conservative seeking to preserve existing social hierarchies, and as an a historical thinker of utopiasconstituted the field of political criticism of Gandhi at the moment of postcolonial transition." While Dasgupta's article says nothing about American politics, its themethe ideological and political dynamics of anti-colonial struggle and post-colonial state-building-is surely relevant to thinking about American politics and especially to the tensions between pastoralism and modernism, and between decentralism and centralism, that have shaped much of American political development. (In his 1909 classic, The Promise of American Life, Herbert Croly framed these tensions as a tension between "Jeffersonian" and "Hamiltonian" perspectives).

Thea Riofrancos's "Scaling Democracy: Participation and Resource Extraction in Latin America" is also not about "American politics," though it is very much about the politics of Latin America, a region inextricably bound up with the politics of the United States. In conventional terms, the piece centers on the contentious politics of resource extraction; the ways that diverse constituencies and social movements, including indigenous movements, politicize public and private policies of land control and natural resource extraction (think "Standing Rock"); and the ways that these contests involve not only policies but also the definition of policy arenas and political boundaries. While the article centers on the case of Ecuador, it raises general questions about different levels of democratic decision-making, of relevance to all polities and especially those, like the United States, organized along federal lines. As Riofrancos writes, "the territorial boundaries of the demos" are always potentially in question: "The concept of scaling democracy draws our attention to the ways in which the collective identities and interests attached to the various scales of democracy are constructed. These interest-articulations and collective identities are shaped by available institutional norms, organizational infrastructures, and social meanings." (There are striking parallels between Riofrancos' account, and arguments made by the recently-deceased political theorist Benjamin Barber, in the just-published book Cool Cities: Urban Sovereignty and the Fix for Global Warming, and in a January 2017 Nation article "In the Age of Donald Trump, the Resistance Will Be Localized: How Cities Can Counter the Power of President Trump.")

As noted earlier, the election of Donald Trump has caused many political scientists to raise serious questions about the "quality" and "health" of democracy in the United States. On December 27, 2016, Vox published a piece by Pippa Norris, Holly Ann Garnett, and Max Gromping on "Electoral Integrity in All 50 U.S. States, Ranked By Experts," which reports on some disturbing findings from their Electoral Integrity Project, a "comparative politics" research initiative focused on general challenges of democratic legitimacy across the range of liberal democratic states. On February 23, 2017, the New York Times published a piece entitled "Democracy in America: How Is It Doing?" The piece reported on a recent survey of over 1,500 political scientists that indicated serious concern about democratic performance in the United States. The article also reports on Bright Line Watch (http://brightlinewatch.org), a new group organized by four prominent political scientists who have published in this journal-John Carey, Gretchen Helmke, Brendan Nyhan, and Susan Stokes-dedicated "to monitor democratic practices and call attention to threats to American democracy. The danger to our democratic norms and institutions has not subsided since the election. It is thus more urgent than ever for scholars to remind leaders and the public how democracy works and to highlight the risks to our system of government."

The next three articles in this issue offer comparative politics perspectives that directly speak to these concerns. Sarah Bush's "The Politics of Rating Freedom" offers a critical account of Freedom House's "Freedom in the World" ratings of countries' freedom, considering the reasons why such ratings have acquired such authority among journalists, policymakers, and scholars. As Bush writes: "Contrary to previous research on private authority, which emphasizes the role of raters' expertise and independence, this paper advances an argument that emphasizes the role of ideological affinity between raters and users." Similar issues were also raised in the March 2017 symposium we ran on Alexander Cooley and Jack Snyder's recent book Ranking the World: Grading States as a Tool for Global Governance, which featured commentaries by Milja Kurki, Pippa Norris, Bo Rothstein, and Philippe Schmitter. And so it seems appropriate that this 
issue also includes Alexander Cooley and Jason Sharman's "Corruption and the Globalized Individual," which "presents a new, more transnational, networked perspective on corruption." Cooley and Sharman challenge "notions of corruption as epitomized by direct, unmediated transfers between bribe-givers and bribe-takers, disproportionately a problem of the developing world, and as bounded within national units." They argue that "the professionals in major financial centers serve to lower the transaction costs of transnational corruption by senior foreign officials. Wealthy, politically powerful individuals on the margins of the law are increasingly globalized as they secure financial access, physical residence, and citizenship rights in major OECD countries." Such a perspective greatly complicates conventional ways of evaluating individual nation-states. It also sheds important light on recent journalistic discussions of "kleptocratic" links between Trump Enterprises and Russian, Chinese, Filipino and Turkish oligarchs-linkages that have played some role in ongoing Congressional and FBI investigations.

Christopher Hobson's "Democratic Peace: Progress and Crisis" raises questions about the "the restricted manner in which the democratic peace research program understands democracy, and considers how its underlying assumptions have left it oblivious to many of the most significant trends now shaping this form of rule." According to Hobson, the democratic peace research program

gives a false sense of stability to democracy, when history shows that its form and meaning have always been more open and in flux than democratic peace research allows for, with crisis being a recurring part of this narrative ... If liberal democracy is undergoing change or is in decline, the greatest threat to the zone of peace may actually be from within. Democratic peace research, however, has spent remarkably little time considering the health of established democracies. This is increasingly difficult to justify given the strong signs of democratic decay and dysfunction present in North America and Europe.

With Katherine Cramer and Benjamin Toff's "The Fact of Experience: Rethinking Political Knowledge and Civic Competence," we return squarely to concerns centering on U.S. politics. Cramer has long been a student of civic engagement and disengagement in the United States. In books such as Talking about Race: Community Dialogues and the Politics of Difference (2001) and Talking about Politics: Informal Groups and Social Identity in American Life (2004) she has explored the ways that ordinary citizens think and talk about the experience of citizenship and its challenges and opportunities (these books were published under the name Katherine Cramer Walsh). As a participant in the American Political Science Association's Task Force on Civic Engagement and Civic Education, she served as a co-author of Democracy at Risk: How Political Choices Have Undermined Citizenship and What We Can Do About It (2005). Most recently, her 2016 book The Politics of Resentment: Rural Consciousness in Wisconsin and the Rise of Scott Walker has received major attention for the ways that it can be read as anticipating the election of Donald Trump. She has been featured on C-Span, National Public Radio, the Public Broadcasting Service (PBS), Scientific American, USA Today, the Washington Post, the New York Times, and a range of other print and broadcast media. Her book has also received extensive scholarly attention, including a symposium in our June 2017 issue.

"The Fact of Experience: Rethinking Political Knowledge and Civic Competence" extends this research program, raising deep questions about how we think about "political knowledge" and "civic competence," and whether conventional approaches-whether in public opinion research or normative political theory-pay sufficient attention to the fine-grained character of political experience. Cramer and Toff "propose an Expanded Model of Civic Competence that presents an alternative interpretation for what it means to be an informed citizen in a democracy. In this model, the competence of listening to and understanding the different lived experiences of others cannot be considered separately from levels of factual knowledge." Cramer and Toff wrestle with "legitimate concerns" about whether their "expanded model" skirts with relativism, and they acknowledge that "lived experience" is not always politically benign, and can involve knowledge commitments - and political commitmentsthat are at odds with core values of liberal democracy. At the same time, they "question whether an Information-Based Model of Civic Competence is the most relevant model for our information-saturated political environment." They thus conclude: Ultimately, awareness of and appreciation for others' experiences
may be as important as knowledge of candidate platforms and the
latest policy debates-matters which are typically held up by the
informed citizen ideal as hallmarks of good citizenship. By
idealizing this particularly elite form of knowledge about political
and public affairs and failing to acknowledge the way marginal-
ized populations engage with the political world, political
scientists may be complicit in delegitimizing these alternative
sources of information, which remain highly relevant to public
life. Experiential knowledge is not only essential to how all
citizens across classes make sense of political phenomena, in
a pluralistic democratic society sharing and conversing about
those experiences remains at the very core of what it means to be
an informed, attentive citizen."

In addressing a very specific research question, Cramer and Toff also raise broader and more fundamental questions that lie at the heart of this journal's distinctive mission: how does political science as a discipline relate to the political world of which it is a part, and how should it relate to this world?

Political science surely has an important role to play in the revitalization of public life, in the United States and beyond. Kieran Healy, in his "Public Sociology in the Age 
of Social Media," furnishes a profound reflection on the challenges facing the Sociology discipline in its pursuit of "public sociology." Healey observes that a range of nolonger-new social media present new opportunities for "public outreach," allowing writers easily to post their own writings and render them accessible without the "intermediation" of editors, publishers, and hierarchies of publication. But he observes that while the new means of communication also have limits, promoting very cursory forms of "viewing" rather than reading and often reinforcing intellectual fragmentation rather than promoting broader forms of public discourse, these new digital technologies are here to stay, and they will continue to shape public discourse and to shape the way that scholarly publication is done. The world of publishing has in many ways become fundamentally "disintermediated," and there is no going back. At the same time, my editorial team and I have worked hard to develop Perspectives on Politics as "a political science public sphere" that is very deliberately edited, and published, with a mind toward broadening discussion both within the discipline and between the discipline and broader reading publics.

We have rejected a merely "curatorial" role for the journal, precisely because we have believed that the obstacles to greater publicity within the discipline are substantial, and can only be surmounted through deliberate and creative effort. In this we have taken our cue from John Dewey, who recognized the challenge in his 1927 classic The Public and its Problems:

The schools may suppose that a thing is known when it is found out ... [but] a thing is fully known only when it is published, shared, socially accessible. Record and communication are indispensable to knowledge. Knowledge cooped up in a private consciousness is a myth, and knowledge of social phenomena is peculiarly dependent upon dissemination, for only by distribution can such knowledge be either obtained or tested. A fact of community life which is not spread abroad so as to be a common possession is a contradiction in terms. Dissemination is something other than scattering at large. Seeds are sown, not by virtue of being thrown out at random, but by being so distributed as to take root and have a chance at growth.

We have sought to sow intellectual seeds, by distributing them so that they might "take root and have a chance at growth."

There remains much work to do to promote broader forms of publicity within the discipline. Fortunately, the political science discipline is a rich, diverse, talented scholarly community, and there are many to do this work in the many ways in which it can be done.

Perspectives is one very important venue, and institution, for this work.

Created by a visionary team led by Founding Editor Jennifer Hochschild, and carried forward with dedication by Jim Johnson, the journal that was bequeathed to us represented the aspirations of a great many colleagues, and we have worked hard to build the journal as a vital and welcoming space for the review and publication of political science scholarship in a variety of formats. I am now thrilled to be turning over the journal to a new editorial team led by Editor in Chief Michael Bernhard and Associate and Book Review Editor Dan O'Neill, who will edit the journal out of the University of Florida. Michael and Dan are exceptional scholars and colleagues, and it has been a great pleasure for James Moskowitz and me to work with them on the editorial transition. Michael has published a number of articles in Perspectives and is a long-time member of our editorial board. Dan has also published in our journal, most recently in the current issue, where he participates in a Critical Dialogue. I am confident that Michael and Dan and their editorial teamtheir editorial staff and their editorial board, which will include a number of holdovers from our board-will do an excellent job with the journal. While much of the material scheduled for publication in the next two issues of the journal has been developed under my editorship, starting with the December issue the journal will be fully theirs and will bear the imprint of their own editorial judgment. I wish them all the best.

Perhaps most importantly, I wish for them the level of involvement and support, professionalism and care, that I have enjoyed from the great many extraordinary colleagues - friends, in the Aristotelian sense and in the personal sense-who have worked with me these past twelve years. I have been blessed. And I am grateful. And with the indulgence of readers, I would like to express my gratitude.

It is hard to know where to start and where to end. And so I'll start with the person who has been with me from beginning to end, and without whose collaboration, friendship, and tireless work and unswerving loyalty and support nothing would have been possible: James Moskowitz. When I first hired James as one of my four Book Review assistants in 2005, he was simply a brilliant young graduate student who had written the only Socratic dialogue ever submitted to me as a final paper in over 35 years of teaching (to be fair, he was not alone; his partner in this dialogic crime was Antje Schwennicke, then a German exchange student, and now an Assistant Professor at Virginia Wesleyan and James' wife). James quickly distinguished himself with the Book Review. And when I was offered the chance to take over the entire journal in 2009, I agreed on only one condition: that James could serve as my Managing Editor. James has worked with many thousands of writers, copy-editors, and production people over the past 8 years. And I'm sure that every single one of those people would attest to his efficiency and his brilliance. He has kept everything running on time, and he has done so with a smile. And he is the most unflappable person I have ever met. When he started he was a graduate student; as we became further and further absorbed in the journal, his role became more than a full-time job, and graduate school 
became a thing of the past. James is a published scholar of international relations. He is an advanced-level French teacher and social studies teacher. He is a tennis pro and a terrific athlete. He is a computer whiz, and his keen aesthetic and artistic sensibilities have made it possible for Perspectives to be a beautifully designed journal, from the cover to the last page of each issue. I will miss working with James. And yet I am sure the deep bond we have shared these many years will only continue to grow.

Margot Morgan was also there at the start. Without her assistance, her enthusiasm, and her support, I would never have agreed to serve as Book Review Editor in the first place. Margot worked with James and me on Perspectives for eight years - a very long time, more than practically anyone has ever worked on any scholarly journal. She started, along with James, as a Review Assistant, and eventually moved on to become Book Review Managing Editor. She was a meticulous organizer of tasks and an equally meticulous proof reader and Mistress of Grammar and Style. Whenever a question of style or formatting arose, we would just turn it over to her. She was a tireless advocate for the political theory subfield whose book review section she oversaw. And she had a unique ability to mock me at all the right moments, to the delight of the staff, the bemusement of me, and the benefit of the strong sense of community that we developed together. Margot was a full partner with James and me for many years. Then she finished her dissertation, published it as a book (Politics and Theatre in Twentieth Century Europe), and decided to leave Bloomington to take a tenure-track position as Assistant Professor of Political Science at Indiana University, Southeast, in New Albany, Indiana.

James and Margot deserve the gratitude of the entire profession.

Over the years we have had an extraordinary staff of Editorial Assistants. Rafael Khachaturian deserves special mention, because he is responsible for the journal's successful social media campaign, and has doubled as a Review Assistant and Social Media Coordinator. Along with James and Brendon Westler, Rafael has been among the most careful readers of everything I write. We have worked with so many terrific people, all of whom did stellar jobs with the journal, and all of whom have moved on to excel at other things, many as recipients of postdocs and then as Assistant Professors. Rebekah Tromble, one our first assistants, indeed is now a tenured Associate Professor at Leiden University! Each person on this list of staff members is much more than a name to me: Laura Bucci, Shanna Dietz, Beth Easter, Adrian Florea, Rachel Gears, Pete Giordano, Emily Hilty, Carolyn Holmes, Luke Mergner, Fathima Mustaq, Hicham Bou Nassif, Katie Scofield, Katey Stauffer, Brendon Westler, and Rafia Zakaria.

I can't say enough about how important it has been to have a staff that is trusted, engaged, involved in every level of journal decision-making and publication, and truly part of a team. I have worked so closely with these people, and I have loved doing so. I have tried hard to make the experience enjoyable and professionally beneficial to each of them. I hope I have succeeded, and I mention this only because I truly believe that professional associations and editors need to do a much better job of recognizing and supporting the work of the graduate assistants who do such indispensable work for our discipline, as editorial assistants and as teaching assistants. Of one thing I am certain: journals like Perspectives could not flourish or even function except for the work of terrific graduate students who almost always labor in obscurity_-something I have been determined to combat.

Equally important is having an editorial board consisting of distinguished colleagues who are dedicated to the journal's mission, willing to work hard, and willing to speak up about matters small and large. I have been blessed with such an editorial board. Every single person who has joined our board has remained on the board for the duration of their terms, and without them, nothing would have been possible. The board played an incredible role during the DA-RT controversy, and took a leadership role in helping our journal to develop an explicit policy on "scholarly recognition" attempting to address questions of citation bias in the discipline. While the board members are all listed on the masthead of this issue, I will list them here as well: Edwina Barvosa, Richard Battistoni, Cristina Beltran, Michael Bernhard, Charli Carpenter, Daniel Drezner, Henry Farrell, Page Fortna, Archon Fung, Ange-Marie Hancock, Marc Morjé Howard, Mala Htun, Bryan Jones, Stathis Kalyvas, Mary Fainsod Katzenstein, Timothy Kaufman-Osborne, Marc Lynch, Samantha Majic, Elizabeth Markovits, Cas Mudde, Daniel Nexon, Melissa Nobles, Erin O'Brien, Paul Pierson, Andrew Sabl, James Scott, Joe Soss, Paul Staniland, Dara Strolovitch, Vesla Weaver, Lisa Wedeen, Deborah J. Yashar, and Cyrus Ernesto Zirakzadeh.

A number of colleagues, most but not all my "senior," have also been incredibly supportive of my editorship, furnishing me with regular advice, including constructive criticism, and constant encouragement: Peter Katzenstein (who appointed me as editor), Larry Jacobs, Ira Katznelson, Bob Keohane, Margaret Levi, Jenny Mansbridge, Suzanne Mettler, Kristen Monroe, Anne Norton, Dianne Pinderhughes, Sandy Schram, Rogers Smith, Sid Tarrow, and Kathy Thelen. Here I must again thank Mary Katzenstein, whose enthusiastic support has been both extraordinary and moving. And I must also thank Mihaela Miroiu, who is one of the pioneers of Romanian political science, the most prominent feminist public intellectual in Romania, and my dear friend and confidante. Over the past two decades, our conversations about the challenges of "institutional harassment" have helped keep me going, just as her own commitment to institution-building has inspired me.

In addition, I'd like to thank some people whose support, behind the scenes, has been essential: Jean 
Robinson, who as Executive Associate Dean of the College of Arts and Sciences at Indiana University helped to secure important College and University support; departmental staff Amanda Campbell, Jessica Williams, Sharon Hughes, Chris McCann, Steve Flinn, and especially Janette Peterson, whose logistical and accounting support of our operations have been indispensable; Linda Lindenfelser and Phylis Berk who served as terrific copyeditors; Mark Zadrozny, Jonathan Geffner, and their colleagues at Cambridge University Press; and the terrific professionals at APSA, especially Michael Brintnall, Regina Chavis, Polly Karpowicz, Kim Mealy, Steven Smith, Betsy Super, and Barbara Walthall, who so kindly produced bound copies of all the issues that I edited as a gift.

Finally, I would not be a political scientist at all were it not for the teaching, guidance, and inspiration offered me, when I first started out many years ago, by some extraordinary individuals: Bob Dahl, Peter Manicas, and Michael Harrington, who are no longer with us; and Ray Franklin, Mike Krasner, and Lenny Markovitz, whose friendship I continue to treasure.
My father, Hyman Isaac, was a linotype operator before that craft was destroyed by cold type and then digital publication. And my mother, Sylvia Isaac, was a secretary, and then office manager, for the American Cancer Society at a time when women of talent and experience could run things but never be put in charge or given proper credit. I thus feel obliged, and moved, to offer special thanks to the many nameless secretaries, office workers, compositors, printers, postal workers, shippers, janitors, and others whose un-thanked labor makes everything that we do possible.

In closing, I would like to thank you, my readers and colleagues, who have entrusted me with one of the treasures of our discipline and thus granted me a precious personal gift, honor, and experience. It has been a true pleasure to work with every author, reviewer, editor, and editorial assistant connected with the journal. Perspectives on Politics has become a visible, respected, and important Political Science Public Sphere. May it live long and prosper.

-May 20, 2017 


\section{Statement of Mission and Procedures}

Perspectives on Politics seeks to provide a space for broad and synthetic discussion within the political science profession and between the profession and the broader scholarly and reading publics. Such discussion necessarily draws on and contributes to the scholarship published in the more specialized journals that dominate our discipline. At the same time, Perspectives seeks to promote a complementary form of broad public discussion and synergistic understanding within the profession that isessential toadvancing scholarship and promoting academic community.

Perspectives seeks to nurture a political science public sphere, publicizing important scholarly topics, ideas, and innovations, linking scholarly authors and readers, and promoting broad reflexive discussion among political scientists about the work that we do and why this work matters.

Perspectives publishes work in a number of formats that mirror the ways that political scientists actually write:

Research articles: As a top-tier journal of political science, Perspectives accepts scholarly research article submissions and publishes the very best submissions that make it through our double-blind system of peer review and revision. The only thing that differentiates Perspectives research articles from other peer-reviewed articles at top journals is that we focus our attention only on work that in some way bridges subfield and methodological divides, and tries to address a broad readership of political scientists about matters of consequence. This typically means that the excellent articles we publish have been extensively revised in sustained dialogue with the editor-me-to address not simply questions of scholarship but questions of intellectual breadth and readability.

"Reflections" are more reflexive, provocative, or programmatic essays that address important political science questions in interesting ways but are not necessarily as systematic and focused as research articles. These essays often originate as research article submissions, though sometimes they derive from proposals developed in consultation with the editor in chief. Unlike research articles, these essays are not evaluated according to a strict, doubleblind peer review process. But they are typically vetted informally with editorial board members or other colleagues, and they are always subjected to critical assessment and careful line-editing by the editor and editorial staff.

Scholarly symposia, critical book dialogues, book review essays, and conventional book reviews are developed and commissioned by the editor in chief, based on authorial queries and ideas, editorial board suggestions, and staff conversations.

Everything published in Perspectives is carefully vetted and edited. Given our distinctive mission, we work hard to use our range of formats to organize interesting conversations about important issues and events, and to call attention tocertain broad themes beyondour profession's normal subfield categories.

For further details on writing formats and submission guidelines, see our website at http://www.apsanet.org/ perspectives/ 